\title{
Stefan Gandler, Fragmentos de Frankfurt. Ensayos sobre la teoría crítica. México: Siglo XXI, 2009, 143 pags.
}

El Instituto de Investigaciones Sociales (Institut für Sozialforschung) fundado en 1922 en la ciudad alemana de Frankfurt fue un intento de entender la sociedad capitalista del primer cuarto del siglo XX. Filósofos, sociólogos, historiadores, economistas, especialistas en derecho y psicólogos elaboraron de forma inter e intradisciplinar toda una serie de reflexiones sobre la sociedad de la época que se denominaron Teoría Crítica. Lo que comenzaron Horkheimer, Adorno, Benjamin, Marcuse y otros, lo continuaron Habermas (segunda generación) o Dubiel y Axel Honneth (con su magnífico trabajo sobre el reconocimiento hegeliano) en la tercera generación. Este es el punto de arranque de Stefan Gandler, un investigador sobresaliente que ha estudiado Filosofía, Ciencias Políticas y Estudios Latinoamericanos en la Goethe Universität de Frankfurt. Su compromiso teórico y práctico (político) le ha llevado a establecerse en México donde ha impartido clases de teoría social en diferentes universidades, como la Universidad Nacional Autónoma de México, la Universidad Autónoma de Ciudad Juárez y la Universidad Autónoma de Querétaro. Sus intereses académicos giran en torno a la teoría crítica, al marxismo y a la “decolonización” filosófica. ${ }^{1}$

En esta ocasión, Gandler trata de mostrarnos el camino para la recuperación del impulso original de aquella teoría crítica desde conceptos muy actuales tales como modernidad, identidad, Estado, historia, dialéctica y antisemitismo, una vez han perdido parte de su significado al ser utilizados de forma descontextualizada o "sobrecontextualizada" (concepto que emplea el propio Gandler). En ese camino de vuelta a los orígenes de la Teoría Crítica, Gandler responde en buena medida en primera persona, es decir, habla desde allí, desde el propio centro alemán. Y se posiciona y se compromete con acierto ético, político y teórico. Ético, por la integridad de sus argumentos, conscientes, competentes y consecuentes; político, porque hace circular todas las ideologías que han jugado un papel relevante en el siglo XX y en la propia Teoría Crítica - nazismo, socialismo (en sus diferentes vertientes) y liberalismo; y teórico, por la profundidad de las reflexiones sobre el marxismo y el capitalismo. Estamos ante un seminario condensado en poco más de cien páginas sobre la construcción de la realidad en el siglo XXI. Son especialmente brillantes las reflexiones sobre el antisemitismo, así como la audacia sentida y mineral con que Gandler ve en el cristianismo el punto de partida de ese antisemitismo de "matar al padre" en el mundo medieval; en oposición a la idea tradicional en la que el concepto de raza está muy discutido y la persecución de los judíos se justifica por haber matado al Verbo.

Gandler muestra igualmente su profundo conocimiento de las teorías referentes a la “decolonización” y su sólida preparación en temas de epistemología. "Los fragmentos que se dan a conocer en las siguientes páginas son de Frankfurt - escribe Gandler -, no sólo porque este nombre, a pesar de ser falso en términos históricos, es de uso común para denominar esta tradición teórica, sino también porque en términos genealógicos tienen una estrecha vinculación con dicha ciudad. No lo decimos tanto en el sentido de Fragmentos ideados en Frankfurt, sino en el sentido de ideas fragmentadas de

\footnotetext{
${ }^{1}$ Su libro más completo es Stefan Gandler, Marxismo crítico en México: Adolfo Sánchez Vázquez y Bolívar Echevarría (México, D.F.: FCE, 2007).
} 
Frankfut”. Este párrafo es una declaración de intenciones de cómo se construye el llamado "geoconocimiento"2 y se inicia un viaje por el conocimiento que va más allá de lo meramente físico. El libro de Gandler es fruto del viaje, del cambio, de los vínculos entre ideas, de aquellas geografías con unas. Es un canto a la deslocalización de las ideas para volver a situarlas, un ejercicio de “nolugarización” de la teoría. ${ }^{3}$ Gandler reivindica el Frankfurt independiente, en el que los docentes judíos podían impartir clases e investigar pese a las leyes antisemitas de la República de Weimar. Para Gandler la ciudad desapareció con el nacionalsocialismo, con la destrucción de los judíos europeos y con la incapacidad de la sociedad alemana post-nazi de romper con todo aquello. Constituyen pilares fundamentales del libro la memoria (individual y colectiva), las guerras culturales en las que el propio Gandler se sitúa como actor - el episodio totalmente "charlotesco" de unas elecciones de sindicatos estudiantiles - y todo el vínculo de la escuela de Frankfurt con el nacionalsocialismo. Se trata de guerras culturales en estado puro. Por algo, Alemania y Estados Unidos son vistas como el centro de esas actividades.

Gandler nos habla de “desesperación teórica”, que es donde la Teoría Crítica rompe con la izquierda clásica, con el movimiento obrero y con el marxismo tradicional (rígido y dogmático como en la URSS). Ese punto es el que lleva a entender la psicología social donde se mezclan el irracionalismo absoluto y la razón instrumental. Marx, pese a sus diferentes observaciones críticas al respecto, nunca pudo ser consciente de que esa combinación llevaría a la destrucción de la humanidad y al genocidio "mejor preparado" de la historia, con dos guerras mundiales que involucrarían a los explotados y a todos los Estados del mundo. Quizá por esto, como bien señala el propio Gandler, la Teoría Crítica fue rechaza por la izquierda, por "blanda”, y por la derecha, por "marxista” (como equivalente al socialismo real).

En este punto, el autor analiza diferentes conceptos vinculados a otros tantos autores. El antisemitismo, tomando como base los postulados de Horkheimer y de Adorno, es el tema central del texto en diferentes niveles, siendo el más importante el ontológico, en el que Gandler explica con claridad cómo la razón necesita de elementos irracionales para su funcionamiento. Es el caso de la memoria, los deseos, los miedos, etc. Tras el antisemitismo, la siguiente parada es la idea de progreso, donde Gandler intenta arbitrar la eterna disputa entre la historia y la filosofía. Su arbitraje es severo y muestra un gran control de la epistemología. El autor controla todos los movimientos y los escruta como si fuera un cuarto árbitro. Así, la principal preocupación, como no puede ser de otro modo, es la mirada hacia atrás del Ángel de la historia en el nivel epistemológico (el entorno), antológicamente (¿existe el futuro?) y políticamente (las generaciones). Nociones como tradición, diferencia, igualdad, "continuun", atrás, pasado, presente, tiempo y futuro pueden conjugarse a partir de lo que Carlos Barros ha denominado Historia Inmediata ${ }^{4}$ (algo que, por cierto, le falta a Gandler).

\footnotetext{
2 Para profundizar en el particular, ver: Claudio Canaparo, Geoepistemology. Latin America and the Location of Knowledge (Frankfurt am Main: Peter Lang, 2009).

3 Tomando como referencia a Marc Augé, Los “No lugares”: espacios del anonimato: una antropología de la sobremodernidad (Barcelona: Gedisa, 1993).

${ }^{4}$ Carlos Barros, "Historia inmediata: marxismo, democracia y socialismo del siglo XXI", Fuentes. Revista de la Biblioteca y Archivo Histórico de la Asamblea Legislativa Plurinacional, La Paz (Bolivia), año 10, vol. 5, 13 (abril 2011): 36-44.
} 
El Estado, la diálectica, Hegel, Marcuse y el eurocentrismo marcan el compás de otro núcleo del libro de Gandler que nos llevan a los "innobles" herederos de Adorno y Horkheimer, especialmente a Dubiel, Honneth y Habermas, donde el primero es el principal objetivo del autor, a quien Gandler hace responsable de una mala "ingesta” del nacionalsocialismo y de sus repercusiones, lecturas y análisis.

Termina Gandler con una serie de propuestas condensadas en trece tesis, todas de alto interés para su estudio y reflexión. En ellas pone en tela de juicio la modernidad en todas sus vertientes contemporáneas: igualdad, libertad e identidad; en definitiva, los cimientos de la sociedad contemporánea y de la actual. El autor relee ese huracán que "sopla desde el paraíso" que es el progreso. Ahora que todos somos más viejos, y que sentimos más frío y somos más grises, notamos que el tiempo es algo inevitable y que viene a por nosotros. Seguramente la nostalgia nos gana en el corazón, pero al preguntarnos cómo hemos descubierto cuándo y dónde, respondemos: ahora y en la "neomodernidad”. Eso es lo que le debemos a Gandler, que no es poco.

Israel Sanmartín

Universidad de Santiago de Compostela. España

israel.sanmartin@usc.es

Fecha de recepción: 15 de diciembre de 2011

Fecha de aceptación: 26 de diciembre de 2011

Publicado: 31 de diciembre de 2011

Para citar: Israel Sanmartín, "Stefan Gandler, Fragmentos de Frankfurt. Ensayos sobre la teoría crítica. México: Siglo XXI, 2009, 143 pags”, Historiografías, 2 (julio-agosto, 2011): pp. 123-125, http://www.unizar.es/historiografias/historiografias/2/3.pdf 